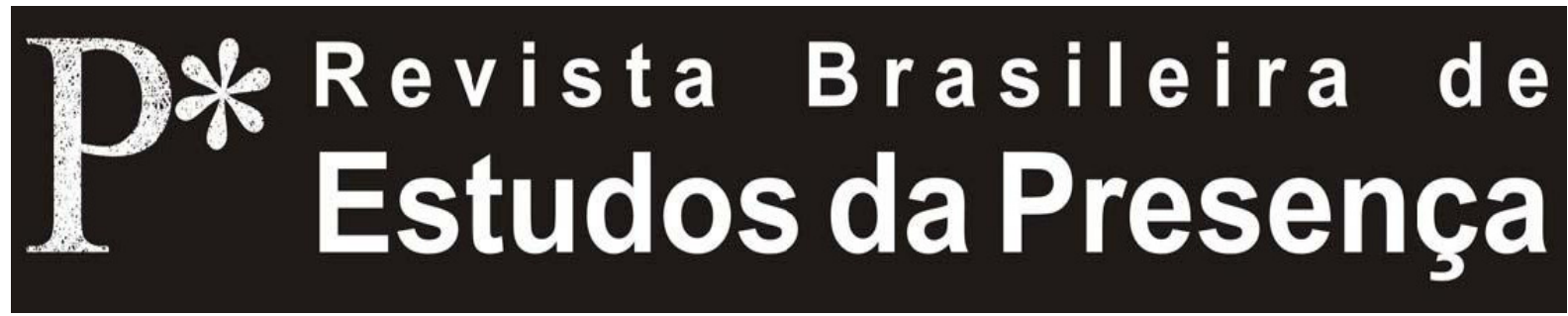

DOI - http://dx.doi.org/10.1590/2237-266038126

ISSN 2237-2660

\title{
Dramaturgias de Ator: puxando fios de uma trama espessa
}

\author{
Alice Stefânia Curi \\ Universidade de Brasília - UnB, Brasília/DF, Brasil
}

RESUMO - Dramaturgias de Ator: puxando fios de uma trama espessa - Dramaturgia de ator é um termo que tenta dar conta do descentramento do discurso textual/verbal para processos de enunciação que emergem das interaçóes complexas do corpo do ator com os demais elementos constitutivos da cena. $\mathrm{O}$ artigo lança um olhar sobre possíveis acepçóes dessa expressão. $\mathrm{O}$ texto dedica-se, ainda, a pensar recursos a serem buscados e princípios que podem orientar as práticas de corpos cênicos.

Palavras-chave: Dramaturgia. Corpo Cênico. Discurso. Sentidos. Práticas.

ABSTRACT - Actor's Dramaturgy: pulling threads from a thick plot - Actor's Dramaturgy is a term that attempts to account for the decentralisation of textual/verbal discourse enunciation processes emerging from complex interactions between the actor's body and other scenic elements. The article presents an overview of the possible meanings of the term, and also thinks the practices and principles which may guide the research on scenic bodies. Keywords: Dramaturgy. Scenic Body. Discourse. Meanings. Practices.

RÉSUMÉ - Dramaturgies de l'Acteur: tirant les fils d'un réseaux épais - Dramaturgie de l'acteur est un terme qui tente de rendre compte du décentrement du discours textuel / verbal qui émerge, dans l'énonciation, des interactions complexes du corps de l'acteur avec d'autres éléments de la scène. L'article se penche sur les acceptions possibles de cette expression. Le texte propose également une réflexion sur les ressources et les principes qui pourraient guider les pratiques des corps scéniques.

Mots-clés: Dramaturgie. Corps Scénique. Discours. Sens. Pratiques. 


\section{Textualidades e Corporeidades}

A importância de discutir a noçáo de dramaturgia de ator se relaciona à necessidade e ao desejo dos artistas cênicos de compreender, corporificar e se corresponsabilizar pelos processos de criação, ficcionalização e composição, bem como pelos modos de construção de sentidos, narrativas e presença cênica. Mobilizada por essa expressão e suas acepçôes, dediquei-lhe uma linha de pesquisa do Grupo Poéticas do Corpo'. Além de contar um núcleo continuado de treinamento, experimentação e criaçáo ${ }^{2}$, o grupo abriga a linha de pesquisa Dramaturgias de Ator, na qual venho orientando projetos de Iniciação Científica, bem como propondo espaços de reflexão do corpo cênico em processos artísticos e pedagógicos ${ }^{3}$. Este texto reflete parte das discussóes e inquietaçóes que emergiram nesse contexto de investigação.

Composição atorial, intérprete-criador e dramaturgia corporal são algumas expressóes que tentam dar conta do descentramento do discurso textual/verbal para processos de enunciação que emergem das interaçôes complexas do corpo do ator - através de suas ações, gestos, estados, construçóes - com os demais elementos constitutivos da cena. Tais terminologias refletem também um processo de maturação criativa e propositiva por parte dos atuantes.

A revisáo do lugar do texto dramático, fazendo emergir um alargamento da própria noção de dramaturgia, que passa a dar conta de outros elementos enunciadores da cena, desdobra-se em problematizaçôes como a da construção logocêntrica e linear da narrativa cênica segundo cânones históricos e a da noção de representação - se a compreendermos, neste contexto, como recurso ilustrativo, redundante ou subserviente à dramaturgia textual ${ }^{4}$. Soma-se a isso a influência da Arte da Performance, com a emergência de produçóes nas encruzilhadas entre arte e vida, cena e plateia, e entre diferentes linguagens artísticas. Fatores como esses vêm fomentar uma transformação na atitude do ator, a qual vem se traduzindo em expressóes como a que dá título a este artigo.

Matteo Bonfitto destaca o potencial enunciativo e a pressáo performativa da materialidade cênica ao pensar a concepçáo dilatada de dramaturgia:

Sendo assim, a noção de dramaturgia como textura, ao admitir um entrelaçamento de camadas produtoras de sentido, não abriria a possibilidade de reconhecimento de uma dra- 
maturgia desvinculada da representação e da ficcionalização? Em sintonia com as tendências dramatúrgicas gerais da performance apontadas por Fabião, a dramaturgia como textura se dá nesse caso através da articulação não de fatos e açôes que remetem a histórias e tramas, mas de qualidades expressivas, de estados, de forças e fluxos que intensificam o acontecimento em processo, gerado pelo contato direto entre performer e público: uma dramaturgia do inefável (Bonfitto, 2011, p. 61).

A busca por outras falas, outras vozes na cena, é refletida por Renato Cohen quando observa que "orquestra-se uma cena polifônica e polissêmica apoiada na rede do hipertexto" (1998, p. xxiv). O espectador vai produzir sua recepção justamente em agenciamentos de sentidos - estéticos, semânticos e patéticos ${ }^{5}$ - que se articulam de maneira nem sempre ordenada e previsível.

Quando corpo e mise-en-scène ganham estatuto dramatúrgico - surgindo prenhes de sentidos próprios e indispensáveis à apreensão do espetáculo -, refletem-se também rupturas paradigmáticas no pensamento ocidental hegemônico. Artaud é um marco emblemático dessa perspectiva. Suas proposiçóes, em especial sua recusa à autoridade patriarcal do texto, sintonizam-se com a provocação nitzschiana da morte de Deus: importante crítica às hierarquias, centralizaçóes, essencializaçóes e metafísicas. Sobre esse contexto, Derrida afirma:

O palco é teológico enquanto for dominado pela palavra, por uma vontade de palavra, pelo objetivo de um logos primeiro que, não pertencendo ao lugar teatral, governa-o à distância. O palco é teológico enquanto [...] um autor-criador ausente e distante, armado de um texto vigia, reúne e comanda o tempo ou o sentido da representação (Derrida, 1971, p. 154).

No início do século XX, Vsévolod Meierhold já investia em dispositivos de teatralidade ao manifestar insatisfaçáo com a preponderância do viés ilustrativo e realista da cena de então. Em estudos sobre sua obra (Picon-Vallin, 2006; Cavaliere, 1996), percebe-se que, ainda que partisse de textos dramatúrgicos propriamente, o encenador se recusava a uma posta em cena previsível, linear e reprodutiva. A busca consciente pela artificialidade 6 teatral, amparada por princípios como o paradoxal, o grotesco, a musicalidade, a corporeidade, a ênfase no desenho, na visualidade e na materialidade da cena, tinha também um teor político. Meierhold desejava uma recepção ativa e crítica por parte do público. A proposital não coincidência entre o discurso verbal, por um lado, e os sentidos corporais e cênicos, por outro, já visava claramente a uma enunciação polissêmica e certo efeito de estranhamento. 
Em seus postulados sobre a biomecânica, Meierhold trazia uma equação que colocava o ator $(\mathrm{N})$ como a somatória entre uma espécie de instância criadora (A1: organizador) e outra executante (A2: material organizado): $\mathrm{N}=\mathrm{A} 1+\mathrm{A} 2$ (Cavaliere, 1996). Em que pesem, nessa matemática, vestígios de uma dicotomia corpo-mente, o que salta aos olhos é o pioneirismo da abordagem, considerando seu lugar histórico. A equação sugere uma legitimação da participação ativa do ator no processo de escolhas, de recortes e até de composição de ações. Certamente seu aprendizado com o mestre Stanislavski, que funda uma pedagogia revendo radicalmente o papel da formaçáo e do trabalho do ator, influenciou ativamente essa perspectiva.

\section{Dramaturgias de Ator: puxando fios de uma trama espessa}

Em 2012, durante o VII Congresso da Associação Brasileira de Pesquisa e Pós-Graduação em Artes Cênicas (ABRACE), em uma sessão de open space durante os trabalhos do GT Processos de Criação e Expressão Cênicos, propus o tema dramaturgias de ator para discussão. O grupo ali reunido chegou a algumas perspectivas sobre a questáo. Para este artigo, retomei minhas anotaçóes e apresento, a seguir, alguns dentre os apontamentos que surgiram. É preciso levar em consideração possíveis lacunas nessa seleção e eventuais ênfases dadas por mim: (1) uma dramaturgia de ator é necessariamente relacional e conectiva, na medida em que o atuante é o principal responsável, no jogo cênico, pelas articulaçóes e fricçóes entre as diferentes dramaturgias da cena; (2) a dramaturgia de ator engloba diferentes camadas e se abre a diferentes procedimentos e poéticas, mas se relaciona à responsabilização, por parte do ator, de seus próprios processos de produção de presença e sentidos; (3) no sentido dessa autonomia e responsabilização, é preciso lembrar que todas as escolhas estéticas e pedagógicas são necessariamente políticas, na medida em que refletem modos de perceber o mundo em suas perspectivas epistêmicas e históricas; (4) ao compreender as especificidades desse campo, cumpre problematizar, pensar e sistematizar pedagogias que viabilizem essa autonomia.

Os pontos levantados durante a sessão no Congresso da ABRA$\mathrm{CE}$ sinalizam a complexidade de perspectivas que vêm à tona ao pensar essa expressáo. Não creio ser possível e tampouco desejável fechar questáo quanto a sua definição. Entretanto, o uso cada vez mais corrente do termo convoca rigor e verticalização da discussão. 
Assim, visando acercar-me da expressão dramaturgia de ator, tento levantar possíveis acepçóes, interaçôes, ou ao menos esboçar discussóes que se relacionem a esta zona de experiência e teorização.

De acordo com Alice Maria Araújo 7 , para os estudos pós-estruturalistas em linguística, a unidade da linguagem não repousa mais no signo, mas no discurso. A partir dele inferem-se mais sentidos que significados. O significado pertence à categoria analítica do signo, enquanto o discurso é uma categoria aberta à (inter)subjetividade e suas coordenadas temporais, actanciais e espaciais. Ainda segundo a professora, sendo histórico, subjetivo e topológico, o discurso cria sentidos, direçôes, vetores no rio da história. Assim, enquanto o significado - na articulaçáo com seu significante - tende a centralizarse em univocidade e monorreferencialidade, os sentidos apresentam contextos, camadas, complexidade, historicidade, desdobrando-se em sensorialidade, vibratilidade, fantasmas, sombras e corporeidades. Se o discurso é compreendido e analisado como apropriaçáo e articulação subjetiva do paradigma que é a língua, podemos dizer que o corpo cênico, ao operar sua sintaxe singular na interaçáo com os elementos da linguagem da cena, também cria discurso, enuncia, mesmo quando calado. Se o significado implica ou indica estabilidade, a significância - categoria processual, rítmica e estética - é instável e inacabada ao promover, dinamicamente, a emergência de uma infinidade de sentidos.

Segundo Marcus Motta ${ }^{8}$, dramaturgia significa etimologicamente "produção (energeia) de acontecimento ou açáo (drama)". Ainda segundo Motta, o vocábulo dramaturgo se refere "àquele que trabalha (érgon) fazendo ou produzindo acontecimentos, açóes, dramas (drama)". Assim, dramaturgia de ator traz a ideia do que se constrói a partir do trabalho do atuante, originando açóes e acontecimentos. Para a pesquisadora Christine Greiner, "a dramaturgia do corpo não é um pacote que nasce pronto, um texto narrado por um léxico de palavras, mas como a própria etimologia propóe, emerge da açáo" (2005, p. 81). Com um maior esgarçamento, a noçáo poderia se abrir ainda à perspectiva ética do campo artístico: o trabalho das ações do ator dentro e fora da cena, não só em âmbitos ficcionais, mas também pedagógicos, técnicos, sociais, afetivos.

Se pensarmos no uso historicamente predominante da expressão, que se refere ao texto escrito, podemos falar, também, em textualidades produzidas por atores. Alguns diretores e dramaturgistas, espe- 
cialmente em processos colaborativos de modo geral, vêm lançando mão de provocaçóes visando tanto à criação de textos ficcionais quanto à composição a partir de depoimentos pessoais por parte dos atuantes. Nesta direção, podemos pensar em um conjunto de narrativas pessoais encenadas ou encenáveis do e pelo corpo cênico, também como um campo circunscrito sob esse termo. De forma cada vez mais assumida e autorizada, memórias, testemunhos e poéticas do sujeito atuante fomentam diferentes obras cênicas.

Ao partirmos da noção alargada de dramaturgia - como vem sendo usada articulada a outros termos, como em dramaturgia da luz, do corpo, de imagens -, chegamos a uma perspectiva que ultrapassa a noção estreita de enunciação como a construção de uma discursividade racionalmente cognoscível. Assim, podemos entender enunciação e discurso de forma dilatada e singularizada, operando como modos de construção, articulaçáo e composição de sentidos. Evoco o filósofo Georges Didi-Huberman e sua filosofia dos sentidos, na qual se relacionam e se tensionam ${ }^{9}$ suas dimensôes semânticas, estéticas e patéticas (1998). Percebo, ainda, na construção atorial, uma dimensão vibrátil (ou energética) de sentido, além das expostas anteriormente, a qual pode ser pensada e experimentada enquanto campo/fonte privilegiada de produçáo de presença.

A noçáo de partitura corporal ou partitura de açóes também se relaciona ao escopo da noção de dramaturgias de ator, caracterizando o percurso e a linha de movimentos, gestos e açóes a ser atuada (no sentido de atualizada) pelo ator ao longo do espetáculo ou performance. Assim, trata-se de conceito importante no universo dramatúrgico operado pelo corpo cênico. Além disso, a expressão convoca a noção de subpartitura, que age de forma imbricada à de partitura, funcionando como uma espécie de forro ou preenchimento ${ }^{10}$ : uma rede de apoios sensórios e motores, um estado ${ }^{11}$, um subtexto. Para Anne Bogart, "[...] o ator estrutura uma paisagem interna complexa e tenta permanecer presente dentro dela" (2009, p. 36).

Um aspecto importante a ser frisado é o fato de que essa a noção aciona uma vocação relacional, já que os sentidos da cena se constroem nos agenciamentos entre os corpos e os demais dispositivos cênicos. Ressalto que não se trata de entender filosoficamente o corpo (ator) como um novo centro da cena, substituindo a centralidade de um texto (autor) ou de uma concepçáo (diretor), mas de perceber a potência vetorial e catalisadora - talvez mais centrífuga do que 
centrípeta - do corpo cênico em suas inter e intratensóes ${ }^{12}$. $\mathrm{O}$ ator é, em situação e em tempo real, peça-chave na articulação entre as diferentes dramaturgias em cena.

Estão em jogo, ainda, no campo dessa expressão, vieses ligados à autonomia nos processos composicionais por parte do ator, sendo fundamental, ainda, que essa busca por maturidade criativa tenha correspondência ética e política. O entendimento do trabalho atorial como efetivamente artístico e (co)autoral - e não apenas executivo ou reprodutivo - responsabiliza sobremaneira o atuante pelos sentidos produzidos em cena.

Conforme síntese poética e conceitual de Fernando Villar ${ }^{13}$, “[...] a arte é mais um campo de paradoxos do que de paradigmas"; é campo também das fricçôes insuspeitadas que ocorrem nos interstícios entre supostas polarizaçóes. A arte do corpo cênico - simultaneamente obra e processo - convoca inúmeras ambivalências. Uma dramaturgia atorial se constrói nos trânsitos, contaminaçóes e reconversóes entre mimesis e poiesis ${ }^{14}$, entre representação e presentificação. Suas pedagogias acionam dimensóes ao mesmo tempo formais e vibráteis. Suas narrativas visíveis e invisíveis agenciam ficcionalidades e realidades muitas vezes indiscerníveis. Suas ações e atualizações são cronotópicas. Seu mister é o de uma constante repetição, sempre diferenciada, atualizada. Sua atuação, ao mesmo tempo que segue um roteiro, programa ou partitura minuciosamente estudada, precisa se dar em fluxo, por devir. O corpo cênico opera em atividade passiva e receptividade ativa ${ }^{15}$, em movimento de plenitude e esvaziamento. Quanto mais presente, concentrado, mais dilatado, poroso, conectivo. Quanto mais inteiro e expandido, maior sua capacidade de apagamento, diluição e dissoluçáo de $\mathrm{s}^{16}$. Seu interno e seu externo decorrem um do outro e escorrem um no outro num continuum ininterrupto.

Segundo Greiner, para pensar essa categoria dramatúrgica corporal, encarnada,

[...] há que se perceber um corpo a partir de suas mudanças de estado, nas contaminaçóes incessantes entre o dentro e o fora (o corpo e o mundo), o real e o imaginado, o que se dá naquele momento e em estados anteriores (sempre imediatamente transformados), assim como durante as prediçôes, o fluxo inestancável das imagens, oscilaçôes e recategorizaçôes (Greiner, 1995, p. 81).

Em relação a processos composicionais a partir de ambivalências e de tensóes entre contrastes, cabe remeter à noção de composição paradoxal proposta por Meierhold, que, segundo a pesquisadora Beatrice Picon-Vallin, construiu sua poética em espaços entre: 
Entre a vivacidade da arte popular e o refinamento da arte erudita. [...] entre a eternidade do teatro de feira e a atualidade dos tablados construtivistas. Entre o trágico e o cômico, entre o familiar e o estranho, entre o cômico e o horrível, entre o belo e o monstruoso. [...] organizar seu corpo, pensar sua atuação e estruturá-la em função dessa série de oposições [...] são operações geradoras de distâncias variáveis, necessárias à criação - para o espectador - de dispositivos de visão ativa, não fusional, estrangeirizante $^{17}$ (Picon-Vallin, 2006, p. 34 - grifos no original).

A esses e outros descritos ainda por essa autora, somam-se contrastes mencionados pela ensaísta e professora Arlete Cavaliere, como aquele entre o plano da dramaturgia textual e do jogo do ator e da encenação, e a dialética entre a surpresa alegre e o assombro por parte da recepção (1996, p. 90). A noção de grotesco, importante nos postulados de Meierhold, está associada à composiçáo paradoxal, ao trânsito e alternância por registros polares e ao efeito de exacerbação e estranhamento que tal jogo promove. Essa perspectiva alimenta o que em Meierhold assume um lugar político: o impacto das fricçóes cênicas sobre o espectador. Segundo Picon-Vallin:

Meierhold designa sua pesquisa sob o termo genérico de grotesco - procedimento ou estilo - que ele define sintomaticamente por seu impacto sobre o público, pelo 'modo constante pelo qual ele arranca o espectador de um plano de percepção que ele mal havia acabado de adivinhar, levando-o para um outro, que ele não esperava'. Esse deslocamento constante dos planos de percepção é tributário de um jogo de contradiçóes, oposiçóes, coerçôes, que articula simultaneamente a expressividade corporal do ator e seu projeto significante (Picon-Vallin, 2006, p. 35).

Nas tensóes entre contrastes, nas quais se dão atritos, dão-se também apropriaçôes, fusões, diferenciações. Meierhold abraçava a perspectiva paradoxal em sua cena porque entendia que "é por meio de uma luta de forças em jogo, e em uma formulaçáo conflituosa, que a atuação alcançará seu mais alto nível de expressividade, encontrará sua acuidade" (Picon-Vallin, 2006, p. 65).

Percebe-se, assim, que a expressão dramaturgia de ator - a qual se aproxima da noçáo de dramaturgia corporal, recortando-a em um contexto teatral - abre uma diversidade de discussóes. Ainda que as acepçóes levantadas anteriormente se tangenciem, se agenciem, se contaminem, se sobreponham e se complementem, a multiplicidade de leituras que a expressão mobiliza justifica seu uso no plural. Várias camadas são acionadas e colocadas em jogo nas dramaturgias atoriais. 


\section{Princípios Pedagógicos para Dramaturgias Atoriais}

Autópsia do coração, por meio do corpo

(Ariane Monouchkine)

Como professora, diretora, atriz e pesquisadora, inquieto-me e me pergunto sobre os recursos importantes na busca desta autonomia composicional e abertura poética. Mais do que atividades e práticas a serem consumidas, que atitudes precisam ser buscadas nessa zona de criação? Levantarei alguns aspectos que certamente náo esgotam o tema, mas que percebo como cruciais ao exercício das dramaturgias de ator. Sei que alguns são termos que carecem de precisão teórica, mas que, por outro lado, têm certa compreensão tácita no campo, especialmente por sua eficácia em contextos de criação atorial. Náo me dedicarei a conceituá-los neste artigo, mas apontarei algumas fontes sempre que possível.

Conforme sugerido anteriormente, vale lembrar ainda que, se tais dramaturgias de ator envolvem uma perspectiva ética e de conduta (o trabalho das ações do ator não só em cena, mas em vida), tornase fundamental refletir sobre o que e como trabalhamos nas salas de aula e ensaio. Que modos de pensar e viver estáo refletidos nas práticas que adotamos e na forma como nos portamos em relaçáo a elas? Assim como a cena e suas poéticas, também as práticas, técnicas e procedimentos carregam historicidade e teor político.

Passo a lembrar, então, alguns princípios (técnicos, éticos, estéticos e energéticos) que podem favorecer o exercício das dramaturgias do corpo cênico.

Práticas meditativas de esvaziamento podem apoiar a criação, já que promovem abertura para devir e acionam processos de desterritorialização, favorecendo a liberação de ideias preconcebidas e de padróes recorrentes. Em algumas dessas práticas, pode ocorrer a instalação do que Denise Sant'Anna nomeia como corpo-passagem. Para ela:

[...] um corpo tornado passagem é, ele mesmo, tempo e espaço dilatados. $\mathrm{O}$ presente é substituído pela presença. A duração e o instante coexistem [...] dissolução da distância entre consciência e inconsciência. [...] Nos corpospassagens é a alma que amadurece em corpo enquanto este abandona sua suposta condição de suporte de inscrição de vontade (Sant'Anna, 2001, p. 105-106).

Tais práticas também facilitam a percepção da dimensão vibrátil do $\operatorname{corpo}^{18}$. 
Indispensável a qualquer processo artístico é a disposição, a abertura e o mergulho no campo da imaginaçáo. Para Ariane Mnouchkine, a imaginação é como um músculo que deve ser "exercitado, fortalecido, trabalhado" (apud Féral, 2010, p. 77). Exercícios perceptivos, práticas de provocação e ampliação dos sentidos (tato, visão, audição, olfato, paladar) e suas traduçôes poéticas e corporais também se configuram como importantes fontes de composições atoriais.

A experimentação e o mapeamento de impulsos visando à produção de presença e dilatação, bem como as investigaçôes acerca das relaçôes entre impulso e ação, são essenciais à percepção e à ativação das potencialidades da corporeidade interna - muscular, óssea, nervosa, fluídica.

Do mesmo modo, é fundamental o desenvolvimento da escuta (no sentido ampliado), do potencial de afecçáo hic et nunc e da percepção da dimensão relacional e conectiva a ser ativada no instante presente. Bogart sintetiza esse princípio quando afirma que "o êxito de um ator é proporcional à qualidade de interaçáo com a resistência inesperada da situação" (2009, p. 39).

Igualmente importante para o corpo cênico é a prática de construção, instalação e reinstalação de estados, subpartituras ou preenchimentos (ainda que essa suposta internalidade possa ser apenas uma superpercepção epidérmica, sensorial) tanto da ordem da intenção quanto da intensão. Para Matteo Bonfitto, enquanto a intenção se aproxima do universo do subtexto e de construçôes mais psicológicas, a intensão remete ao campo das latências e intensidades ${ }^{19}$.

O exercício das dramaturgias de ator exige também habilidade e sensibilidade em composiçáo ${ }^{20}$. São importantes os processos de geração e seleção de matrizes corporais; o estudo das possibilidades de desdobramento dessas matrizes acionadas por outras subpartituras e contextos; a escavação e a lapidação ${ }^{21}$ tanto das ações derivadas de matrizes quanto das transiçóes entre estados e açóes. Outra perspectiva interessante é a exploração dos materiais com uso de parâmetros como tempo, amplitude, intensidade, segmentação, sobreposição, repetição, diferentes ordens e transiçóes etc ${ }^{22}$.

Também deve ser explorada a percepçáo das dimensôes intra e intertensivas, que se referem respectivamente a vetores de tensóes internos a cada corpo e jogos de tensôes entre o conjunto de corpos no espaço. As experiências e o treinamento do corpo temporalizado e espacializado, tanto nos processos de composiçáo singular - a partir 
dos materiais expressivos de um único corpo - como no exercício das possibilidades de composição coletiva - percepção e jogo entre vários corpos no espaço-tempo-, são ferramentas cruciais para o ator ${ }^{23}$.

A aprendizagem da contenção ou retenção, traduzida e descrita por Barba como virtude da omissáo (1994), e explicitada também na colocação de Zeami: "Quando sentir dez no coração, expresse sete" (apud Bogart, 2009, p. 34), também pode tornar-se um recurso importante nos processos de lapidação e ajustes de materiais expressivos.

Outro princípio operatório basilar a ser exercitado pelo ator é a organicidade, compreendida aqui como uma liga, uma lógica interna nervosa, vibrátil e afetiva entre os elementos de uma composição, sendo que essa articulaçáo náo aponta necessariamente para um sentido de coesão, podendo ressaltar justamente as dissonâncias, desvios e rupturas performativas.

O corpo cênico precisa ainda desenvolver prontidão - no sentido da expressão to be decided (Barba, 1994), que aponta para o trânsito entre proposição e aceitação, e o fluxo entre reação, apropriação e transformação. É preciso, além disso, ter disposição para explorar, mapear, esgarçar, recontextualizar, redimensionar e lapidar materiais criativos e para driblar zonas de conforto. Por fim, é indispensável que se desperte a consciência acerca da dimensáo complexa e política da cena e do papel do corpo cênico em sua produção de sentidos nesse contexto.

Tentei apontar alguns aspectos que considero fundamentais para a conquista de uma autonomia artística. Mais do que descrever, buscar ou sugerir práticas, parece-me importante pensar sobre aquilo que se quer alcançar e trabalhar com tais práticas. É preciso refletir sobre o que desponta como re-curso ${ }^{24}$ imprescindível, como princípio fundamental no exercício das dramaturgias atoriais. Inúmeras práticas podem servir a diferentes propósitos, o que torna essencial a reflexão tanto sobre aquilo que desejamos alcançar com elas quanto como podemos torná-las eficazes a esses propósitos. Nesse sentido, destaca-se mais uma vez a importância da maturidade e porosidade do ator em relaçáo à qualidade de sua experiência no tempo-espaço de sua pesquisa cênica.

\section{Poéticas do Corpo ${ }^{25}$}

No coletivo Poéticas do Corpo, o qual abriga as linhas de pesquisa Teatro do Instante e Dramaturgias de Ator, exploramos 
princípios de trabalho que fomentem tanto poéticas corporais como exercício artístico (busca por recursos expressivos e composicionais) quanto uma perspectiva mais ampla da noçáo de um trabalho do ator sobre si mesmo. Esse trabalho envolve a dimensão da alteridade na qualidade das relaçóes (um ethos de grupo) e a vivência e refinamento de nosso corpo sutil/vibrátil. Assim, o treinamento não é vivido apenas como um espaço de repetiçáo e aprimoramento técnico, mas também como um lugar de experiências e afecçóes transbordadas em expressividades. Experiência em fluxo, em um continuum entre singularidade e alteridade, interno e externo, afetos e poéticas.

Com a experiência junto ao grupo, tenho pensado a noçáo de dramaturgia atorial a partir das várias perspectivas apontadas anteriormente. $\mathrm{O}$ ator na contemporaneidade reivindica criação, recusando-se a meramente reproduzir autorias e autoridades prévias e alheias, seja na forma de textos, marcas ou partituras concebidas dissociadas de si, ao mesmo tempo que experimenta e exercita suas possibilidades expressivas para além de signo de representação unívoca e ilustrativa.

Nessa perspectiva, a corporeidade configura-se náo como um novo centro hierárquico da cena, ao qual convergem os demais elementos, mas como um motor relacional, uma usina de onde se irradiam forças, tensôes, vetores de enunciação. Estão em jogo fricções do corpo consigo mesmo, com outros corpos e com toda a materialidade cênica. Mais que conflitos à moda psicológica, são turbulências, fissuras, fraturas, atritos. A noção de dramaturgia de ator articula-se a essa potência de produção e desestabilizaçáo do signo a partir de açóes do corpo em cena. Dramaturgias atoriais tensionam a enunciação semântica a uma constelação de latências: sentidos que emergem de experiências sensoriais, associativas, mnemônicas, emotivas, vibráteis.

Por fim, nossa prática como grupo envolve um viés de conduta que percebo como uma trama, em seu duplo, recíproco e desdobrável sentido: de constelação e de conspiração. Constelação por seu caráter rizomático e múltiplo de agenciamentos e reinvenção nas diferenças, assim como pelo entrelaçamento de princípios éticos e estéticos. Conspiração em seu aspecto de maquinação, estratégia de atuação na vida, micropolítica feita no dia-a-dia, nas priorizações, nos afetos, nas salas de aula e de ensaio, nas escolhas e qualidade das relaçóes. 


\section{Notas}

${ }^{1}$ Coletivo coordenado por mim e pela atriz, diretora e professora doutora Rita de Almeida Castro, registrado no Diretório de Grupos do CNPq. Disponível em: <http://poeticascorpo. blogspot.com.br/>.

${ }^{2}$ Linha de pesquisa Teatro do Instante. Disponível em: <http://poeticascorpo.blogspot. com.br/p/teatro-do-instante.html>.

${ }^{3}$ Linha de pesquisa Dramaturgias de Ator. Disponível em: <http://poeticascorpo.blogspot. com.br/p/dramaturgias-de-ator.html >.

${ }^{4} \mathrm{O}$ conceito de representação é complexo e absolutamente não se esgota nessa perspectiva. Aludo aqui a uma discussão frequente no campo teatral, a qual contrapóe uma atuaçáo do campo da representação a uma atuação da ordem da presentação ou presentificação. Grosso modo, essa polarização trabalha com uma ideia de representação enquanto um processo de substituição da presença em si por uma construção que a simbolize. Na nota 14, está esboçada uma discussão, levantada por Renato Cohen (1998), que reflete um pouco essa questão.

${ }^{5}$ Esse triplo entrelaçamento é proposto por Georges Didi-Huberman (1998). O autor refere-se a um complexo de naturezas de sentido no processo de recepçáo entre as vias de apreensão sensorial (estética), racional (semântica) e emocional ou sintomática (patética).

${ }^{6}$ Compreendida aqui não como refutatória à verdade cênica, mas como um dispositivo cênico em que as construçóes são deliberadamente reveladas como construçóes, em contraponto com uma perspectiva mais ilusionista da cena.

${ }^{7}$ Linguista, dicionarista e professora doutora da Universidade de Brasília. Notas de aula durante o curso de extensão Linguagens de Especialidades, ministrado pela professora Alice Maria Araújo e coordenado por mim, no Departamento de Artes Cênicas da UnB, em março de 2013.

${ }^{8}$ Dramaturgo e doutor em Estudos Clássicos, professor do Departamento de Artes Cênicas da Universidade de Brasília. Informação obtida em consulta verbal, em abril de 2013.

${ }^{9}$ Propositalmente $\operatorname{com} s$, já que se refere a um jogo de tensóes.

${ }^{10}$ Conferir em Eugênio Barba (1994) e o verbete subpartitura em Patrice Pavis (2003).

${ }^{11}$ No sentido dado por Ariane Mnouchkine: "O mais importante é encontrar sua situação, seu estado. Vocês precisam de um estado puro, de uma sequência de estados muito puros. [...] Acreditar é o mais importante. [...] O problema de vocês é traduzir o estado. [...] Traduzir algo de imaterial, traduzir uma emoção num corpo. É por meio do corpo que essa emoção se opera" (apud Féral, 2010, p. 63-64, grifos no original).

${ }^{12}$ Conferir as noções de intratensão, intertensão e infratensão em Maura Baiocchi e Wolfgang Pannek (2007).

${ }^{13}$ Diretor, encenador e dramaturgo. Professor doutor do Departamento de Artes Cênicas da Universidade de Brasília. Informação verbal obtida em palestra no espaço Entre do CCBB Brasília, em 08 de janeiro de 2013. 
${ }^{14}$ Conforme os sentidos dados por Renato Cohen (1998). Para o autor, a Arte da Performance instauraria uma cena da ordem da poiesis em contraposição à cena da mimesis. Ele propóe as seguintes definiçóes: "Poiesis enquanto cena gerativa, primária, abstrata - com estatuto próprio enquanto realidade, sem contraponto. Mimesis como cena reprodutiva, iconográfica, secundária a uma realidade primeira" (1998, p. 9). A meu ver, parece difícil imaginar uma criação cênica, em especial na contemporaneidade, pautada exclusivamente em mimesis ou em poiesis. Mesmo que se distanciem e até se oponham em alguns aspectos, sáo princípios que não se excluem no trabalho atorial; ao contrário, apresentam uma complementaridade que parece bastante fértil aos processos criativos cênicos.

${ }^{15}$ Para Mnouchkine, “[...] o ator é um receptáculo ativo, e isso não é contraditório [...] Côncavo para receber e convexo para projetar" (apud Féral, 2010, p. 62).

${ }^{16}$ Além da referência clara à via negativa de Jerzy Grotowski, lembro Ariane Mnouchkine, para quem "a presença progride com a capacidade de desnudar-se de um ator" (apud Féral, 2010, p. 76). O Grupo de Pesquisa Poéticas do Corpo promove residências e trocas periódicas com outros artistas. Em um desses processos de formação, com o ator e pesquisador Carlos Simioni do grupo de pesquisa Lume da Unicamp, presenciei (e experimentei) um trabalho ao qual ele chamou doação, no qual tive a nítida impressão de que seu corpo ia apresentando progressivamente uma espécie de transparência, de apagamento, ao mesmo tempo em que sentia vindo dele uma intensa irradiação vibrátil.

${ }^{17}$ Essa perspectiva estrangeirante é responsável pela aproximação que alguns estudiosos fazem entre a obra do encenador russo e a de Bertold Brecht. O efeito de estranhamento é relacionado ainda, por alguns autores, à noção meierholdiana de pré-jogo (ou préinterpretação).

${ }^{18}$ Em relação aos processos de esvaziamento e mapeamento vibrátil, menciono sucintamente alguns procedimentos usados em nosso grupo de pesquisa. Chi kung - traduzido simplificadamente como trabalho com energia; é um conjunto de procedimentos de origem chinesa, ligados à tradição taoísta. Objeto de estudo em minha tese de doutorado (2007), descrito em meu livro Traços e devires de um corpo cênico (2013). Seitai-ho - conjunto de práticas corporais de origem japonesa; objeto de estudo da tese de doutorado da Professora Rita de Almeida Castro (2012), minha parceira na coordenação do Grupo de Pesquisa Poéticas do Corpo. "O seitai-ho é um caminho de vida natural e integral sustentado por um conjunto de técnicas. Seus treinamentos afinam a sensibilidade e o movimento corporal através da percepção interna" (Disponível em: <http://www.jardimdosventos.com/>). Yoga da voz - a técnica trabalha o som, a voz e o canto em suas dimensóes estéticas e terapêuticas. É ligada ao projeto Vox Mundi, cuja "abordagem é integral, transcultural e sistemática. $\mathrm{O}$ treinamento, prioritariamente vivencial, oferece uma integração precisa das técnicas orientais e ocidentais do canto como arte terapêutica... uma vasta gama de técnicas vocais de diferentes culturas é explorada através da prática de formas indígenas e clássicas de culturas tão diversas quanto a europeia, a tibetana, a brasileira (especialmente indígena), da África e da Índia” (Disponível em: <http://yogadavoz.blogspot.com.br/>).

${ }_{19}$ Perspectiva apresentada por Matteo Bonfitto em fala na Universidade de Brasília, em ocasião de uma colaboração do pesquisador junto ao grupo Poéticas do Corpo, em abril de 2011. 
${ }^{20}$ Ver mais sobre esse conceito aplicado às artes da cena em Bonfitto (2002).

${ }^{21}$ Venho usando o que aqui defino como metáforas arqueológicas para o trabalho atorial inspirada por Matteo Bonfitto, que vem colaborando com o grupo de pesquisa Poéticas do Corpo.

${ }^{22}$ No livro Traços e devires de um corpo cênico (2013), apresento um rol de sugestóes de imagens ligadas à sabedoria taoísta como fonte para geração de matrizes expressivas para o corpo cênico. Também proponho a utilização de diferentes pares ligados ao sistema de classificaçáo yin yang, como possibilidades de trabalho de gradiente de material corporal. Por exemplo, a provocação de se experimentar uma qualidade de movimento de modo mais frio ou mais quente, mais denso ou mais sutil etc.

${ }^{23}$ Rudolf Laban é uma forte referência no trabalho de exploração de movimentos a partir das relaçóes com temporalidade e espacialidade. O trabalho a partir dos viewpoints metodologia de composição cênica desenvolvida e descrita por Anne Bogart e Tina Landau (2005) - igualmente apresenta ferramentas interessantes para o trabalho com tempo e espaço. Para processos de composição coletiva, além desse último, aprecio também a prática do campo de visáo. Marcelo Lazzaratto tem um estudo importante e bastante útil sobre desdobramentos de pesquisa com o campo de visáo (2011). Na oficina O teatro é o outro, que fiz em 2011 com Maurice Durozier, ator do Theatre du Soleil, ele também se valeu dessa prática, a qual nomeou, na ocasiáo, coro grego.

${ }^{24}$ Re-curso enquanto princípio operatório ao qual recorrer, e no sentido de algo a ser recursado, acionado novamente, sempre em perspectiva espiralada, o mesmo princípio, mas atualizado, diferenciado a cada vez.

${ }^{25}$ Esta última seção do artigo, que se refere ao Grupo de Pesquisa Poéticas do Corpo, contém trechos retirados de meu livro Traços e devires de um corpo cênico (2013), no qual narro minha pesquisa de doutorado.

\section{Referências}

BAIOCHI, Maura; PANNEK, Wolfgang. Taanteatro: teatro coreográfico de tensões. São Paulo: Azougue Editorial, 2007.

BARBA, Eugênio. A Canoa de Papel. São Paulo: Hucitec, 1994.

BOGART, Anne; LANDAU, Tina. The Viewpoints Book: a Practical Guide to Viewpoints and Composition. New York: Theatre Communications Group, 2005.

BOGART, Anne. Seis Coisas que Sei sobre o Treinamento de Atores. Revista Urdimento, Santa Catarina, CEART/UDESC, v. 12, p. 29-40, mar. 2009. Disponível em: <http:// www.ceart.udesc.br/ppgt/urdimento/2009/urdimento_12.pdf>. Acesso em: 05 ago. 2013.

BONFITTO, Matteo. O Ator-compositor: as açóes físicas como eixo: de Stanislavski a Barba. Sáo Paulo: Perspectiva, 2002.

BONFITTO, Matteo. Tecendo os Sentidos: a dramaturgia como textura. Revista Pitágoras 500, Campinas, IA/Unicamp, v. 1, p. 56-61, out. 2011. Disponível em: <http://www. publionline.iar.unicamp.br/index.php/pit500/article/view/17/19>. Acesso em: 05 ago. 2013. 
CASTRO, Rita de Cássia de Almeida. Ser em Cena, Flor ao Vento: etnografia de olhares híbridos. Brasília: UnB, 2012.

CAVALIERE, Arlete. O Inspetor Geral de Gogol/Meierhold: um espetáculo síntese. São Paulo: Perspectiva, 1996.

COHEN, Renato. Work in Progress na Cena Contemporânea: criação, encenação e recepção. São Paulo: Perspectiva, coleção Estudos, 1998.

CURI, Alice Stefânia. Por uma TAO Expressividade: processos criativos em trânsito com matrizes taoístas. 2007. Tese (Doutorado em Artes Cênicas) - Programa de Pós-Graduação em Artes Cênicas, Universidade Federal da Bahia, Salvador, 2007.

CURI, Alice Stefânia. Traços e Devires de um Corpo Cênico. Brasília: Dulcina, 2013.

DERRIDA, Jacques. A Escritura e a Diferença. São Paulo: Perspectiva, 1971.

DIDI-HUBERMAN, Georges. O que vemos, o que nos olha. São Paulo: 34, 1998.

FÉRAL, Josette. Encontros com Ariane Mnouchkine: erguendo um monumento ao efêmero. São Paulo: SENAC/SESC, 2010.

GREINER, Christine. Por uma dramaturgia da carne. In: BIÃO, Armindo; PEREIRA, Antônia; CAJAÍBA, Luiz Cláudio; PITOMBO, Renata. Temas em Contemporaneidade, Imaginário e Teatralidade. Sáo Paulo e Salvador: Annablume/GIPECIT, 2000. P. 354-364.

GREINER, Christine. O Corpo. Pistas para estudos indisciplinares. São Paulo: Annablume, 2005.

LAZZARATTO, Marcelo. Campo de Visão: exercício e linguagem cênica. São Paulo: Escola Superior de Artes Celia Helena/FAPESP, 2011.

PAVIS, Patrice. Dicionário de Teatro. São Paulo: Perspectiva, 2003.

PICON-VALLIN, Beatrice. A Arte do Teatro entre Tradição e Vanguarda: Meierhold e a cena contemporânea. Rio de Janeiro: Letra e Imagem, 2006.

SANT’ANNA, Denise. Corpos de Passagem. São Paulo: Estação Liberdade, 2001.

Alice Stefânia Curi é atriz, diretora e pesquisadora. Doutora pelo Programa de PósGraduação em Artes Cênicas da Universidade Federal da Bahia. Professora adjunta do Departamento de Artes Cênicas da Universidade de Brasília, Brasília, Distrito Federal, Brasil. Coordenadora do grupo de pesquisa Poéticas do Corpo.

E-mail: alicestefania@gmail.com

Recebido em 25 de março de 2013

Aprovado em 10 de julho de 2013 